


\section{LEGAL NOTICE}

This report was prepared as an account of Government sponsored work. Neither the United States, nor the Commission, nor any person acting on behalf of the Commission:

A. Makes any warranty or representation, expressed or impled, with respect to the accuracy, completeness, or usefulness of the Information contained in this report, or that the use of any information, apparatus, method, or process disclosed in this report may not infringe privately owned rights; or

B. Assumes any liabllities with respect to the use of, or for damages resulting from the use of any information, apparatus, method, or process disclosed in this report.

As used in the above, "person acting on behalf of the Commission" includes any employee or contractor of the Commission, or employee of such contractor, to the extent that such employee or contractor of the Commission, or employee of such contractor prepares, disseminates, or provides access to, any information pursuant to his employment or contract with the Commision, or his employment with such contractor.

Printed in USA. Price $\$ 1.00$

Avallable from the Clearinghouse for Federal Sclentif-ic

and Technical Information, National Bureau of Standards,

U. S. Department of Commerce, Springfield, Virginia 
664375

$D P-985$

Chemistry

(TID-4500, 45th Ed.)

\title{
AUTOMATED ANALYSIS OF LITHIUM SOLUTIONS
}

\author{
by
}

Rufus H. Gaddy

Approved by

E. L. Albeneslus, Research Manager

Analytical Chemistry Division

October 1965

E. 1. DU PONT DE NEMOURS \& COMPANY

SAVANNAH RIVER LABORATORY

AIKEN, SOUTH CAROLINA

CONTRACT AT(07.2).1 WITH THE

UNITED STATES ATOMIC ENERGY COMMISSION 


\begin{abstract}
An automated flame photometric method was developed for the precise determination of lithium in highly radioactive process

solutions contalning curlum, americium, and fission product radionuclides.
\end{abstract}




\section{CONTENTS}

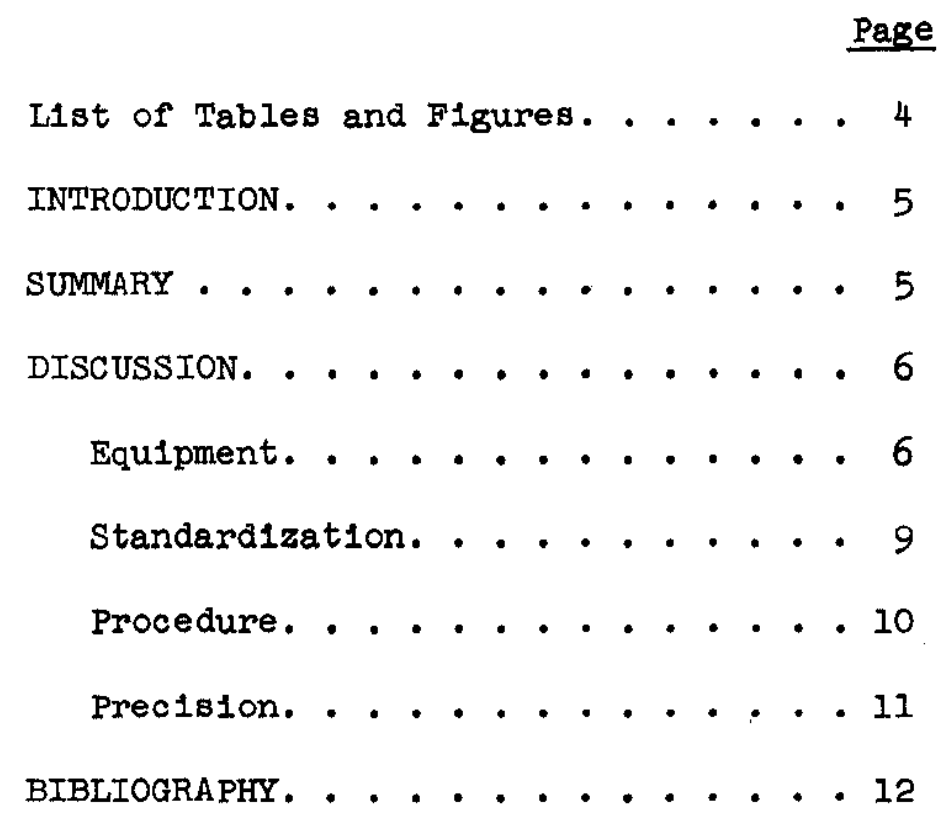




\section{LIST OF TABLES AND FIGURES}

Table

I Precision of Automated Flame Photometric Lithium

Method. . . . . . . . . . . . . . . . .

\section{F1gure}

I Calclum Fluoride Column . . . . . . . . . . . . 7

2 Flame Photometer Attachment with Proportioning Pump and Automatic Sampler . . . . . . . . . . . . . 7

3 Flame Photometer Burner . . . . . . . . . . . . 8

4 Recorder Trace of Noise Level During Time Required for Analysis of Sample and Standards. . . . . . . . . . 8

5 Itthium Calibration Curve . . . . . . . . . . . . 9

6 Flow Diagram for Automated Lithium Method . . . . . 10

7 Recorder Chart Showing Ratios of Intensities of L1 670.8 mu Lines to K $766.5 \mathrm{m \mu}$ Iines for Standards and Sample. 


\section{AUTOMATED ANALYSIS OF LITHIUM SOLUTIONS}

\section{INTRODUCTION}

In the recovery of americium and curlum in the Tramex separations process, these elements are extracted from an IIM IIthlum chloride solution into a mixture of tertiary amine chlorldes in diethylbenzene. Because the extraction of amerlclum and curlum is strongly dependent on the lithium concentration, an analytical method was required for determining lithium with a high degree of accuracy and precision.

The high radiation level of the Tramex process feed solution is a primary consideration in the analytical methods to be considered. Chemical methods $(1,2)$ are, in general, not specific for 11thium, are long and tedious, and require large samples for welghing lithium as lithium sulfate. These disadvantages of the chemical determination of lithium in a highly radioactive solution prompted the search for an instrumental method. The polarographic determination(3) of the alkali metals with tetraethylammonium hydroxide as the supporting electrolyte is not precise enough to meet the specifications in the Tramex process.

Conventional flame photometric equipment has been used to measure the lithium concentration of samples that were separated from radioactive lanthanides and actinides by passage through a calcium fluoride column. (4) Under 1deal conditions, a relative standard deviation of $2 \%$ was attalned, but in routine analysis the precision was less, and adequate control of the process was difficult. Although flame photometric methods are claimed to be precise to only $2-3 \%$, 1t appeared feasible to develop an automated flame photometric method for determining lithium with a higher degree of precision.

\section{SUMMARY}

A flame photometer attachment was adapted for use with the "AutoAnalyzer"* to provide an automated analytical method for the routine determination of lithium in Tramex process solutions. This method has been used successfully in the course of the development of the Tramex process at the Savannah River Laboratory.

Radioactive lanthanides and actinides are removed from the Tramex solution by passing the sample through a calcium fluoride column before analysis. The purified solution is fed through the "AutoAnalyzer" where

*Trademark of Technicon Controls, Inc., Chauncey, N. Y. 
It is mixed with a potassium internal standard, and is then fed to the burner of the photometer. Light from the flame is passed through interference filters and the ratio of the Intensity of the lithium line to that of the potassium line is recorded.

The relative standard deviation for the analysis of Tramex feed solutions is $\pm 1.4 \%$. The comblned nolse level and drift of the instrument system represents only $\pm 0.2 \%$ error.

\section{DISCUSSION}

\section{EQUIPMENT}

The equipment cons1sted of a calc1um fluoride column, an "AutoAnalyzer" proportioning pump and automatic sampler, and a flame photometer attachment for the "AutoAnalyzer." The preparation of the calcium fluoride column (5) (shown in Figure 1) and the operation of the proportioning pump $(8)$ and automatic sampler ${ }^{(7)}$ have been described.

The flame photometer(7) attachment shown in Figure 2 was designed for the determination of sodium and potassium in blood serum with lithium used as an internal standard. Since the photometer was designed for the output signal to be proportional to the ratio

$$
\text { sodium or potassium concentration, }
$$

\section{1thium concentration}

the interference filters were rearranged in the1r semipermanent positions to give an output signal that was directly proportional to the lithium concentration.

The unusual features of the flame photometer are a uniquely designed burner and a bullt-in range expander. The range expander provides a threefold expansion of the recorder scale. The burner is shown in Figure 3. Propane and oxygen, each at $10 \mathrm{ps} 1 \mathrm{~g}$, are mixed in a metal chamber prior to entering the burner. The main flame gases 1ssue through the annulus surrounding the sample cap1liary at speeds adequate for atomization of the liquid sample stream. The auxiliary flame burns at the tips of the three capillaries located symmetricaliy at the perlphery of the burner and stabllizes the main flame. For accurate control of gas flow rates and flame conditions, both oxygen and propane are metered individually for each flame. The emitted light of interest, $\mathrm{L} 1670.8 \mathrm{m \mu}$ and $\mathrm{K} 766.5 \mathrm{m \mu}$, $1 \mathrm{~s}$ select1vely isolated by interference filters and detected with cadmium sulfide photocells. The ratio of the signals from the photocelis activates a strip chart recorder. The absence of drift and the low nolse level of this automated method for a steady state condition are shown in Figure 4. The nolse level represents an error of $\pm 0.2 \%$ in the method. 


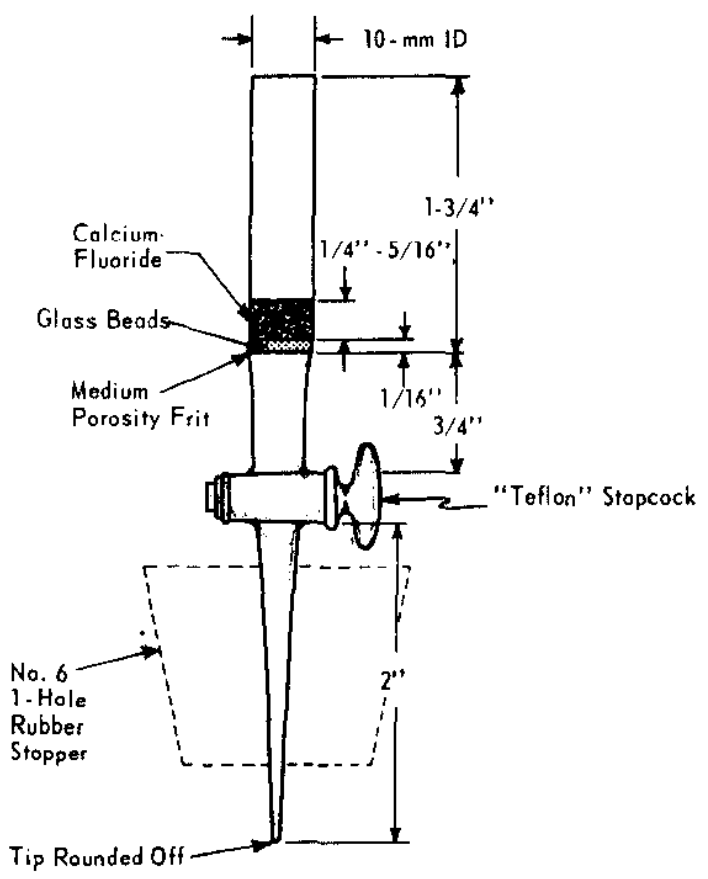

FIG. I CALCIUM FLUORIDE COLUMN

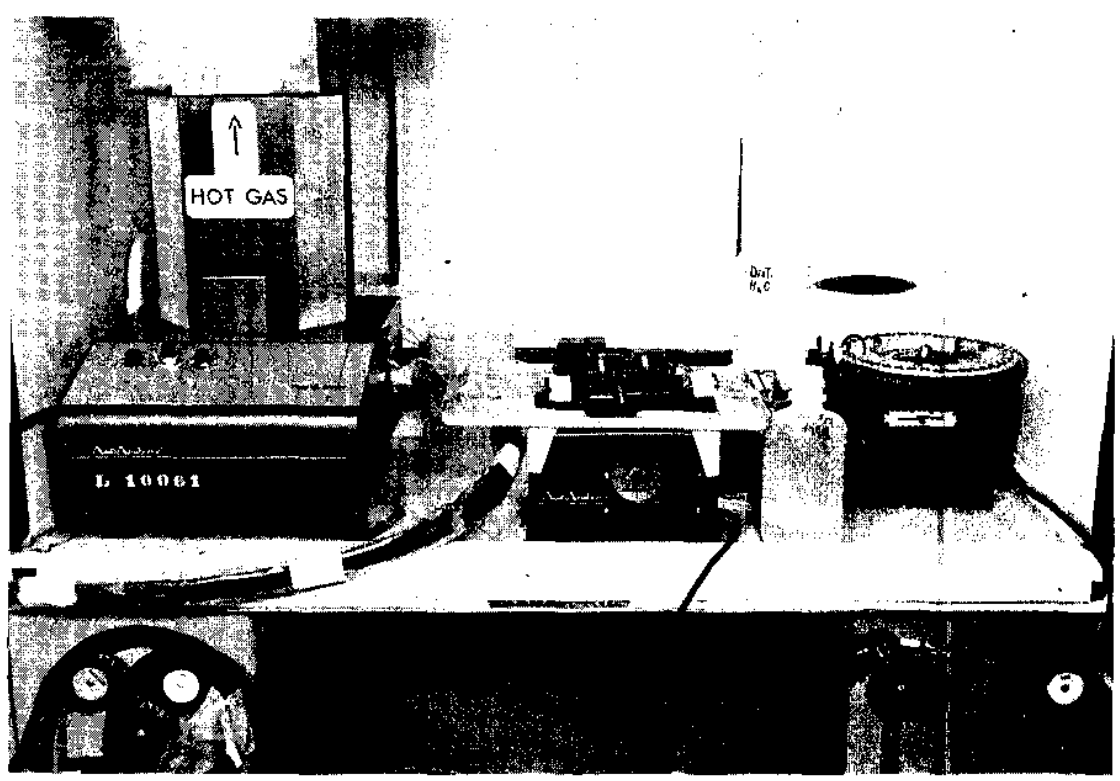

FIG. 2 FLAME PHOTOMETER atTACHMENT WITH PROPORTIONING PUMP AND AUTOMATIC SAMPLER 


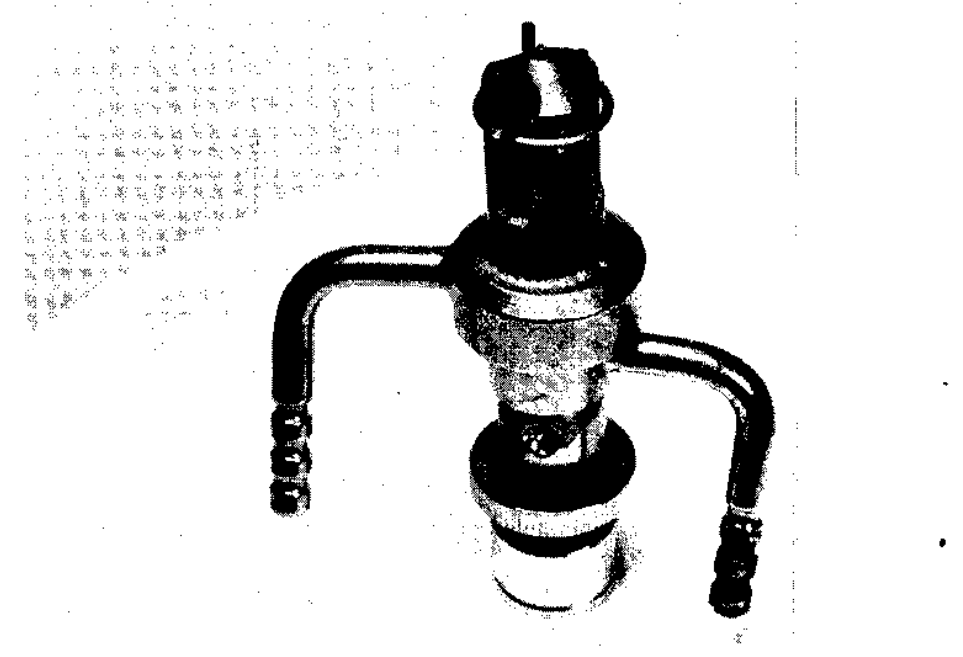

FIG. 3 FLAME PHOTOMETER BURNER

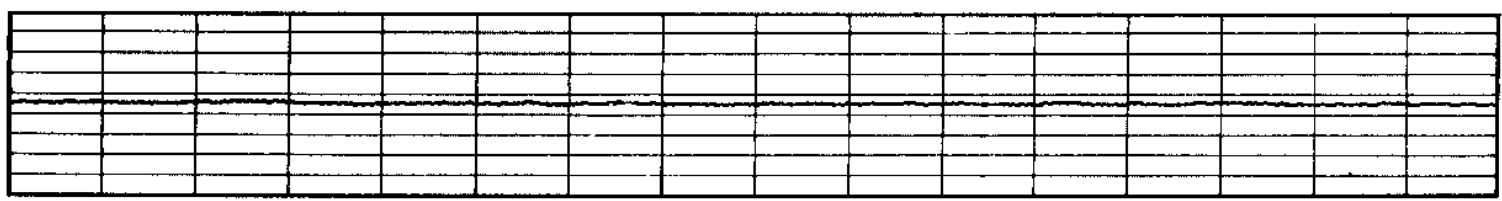

FIG. 4 RECORDER TRACE OF NOISE LEVEL DURING TIME REQUIRED FOR ANALYSIS OF SAMPLE AND STANDARDS 


\section{STANDARDIZATION}

Powdered 11thium chloride (Allied Chemical Co., Reagent Grade) was dried at $110^{\circ} \mathrm{C}$ for 24 hours. Calcium, barium, lead, tin, and iron, each at less than $0.01 \mathrm{wt} \%$, were detected in the powder by spectrographic analysis. These analyses conflrmed the manufacturer's assay of 98.0 wt $\%$ LICI.

Standard solutions of 8 to $12.5 \mathrm{M} \mathrm{L1Cl}$ were prepared from the dried powder. These solutions were diluted $1000-\mathrm{fold}$ and adjusted to $0.05 \mathrm{M}$ $\mathrm{HNO}_{3}$ and $0.03 \mathrm{~g} \mathrm{La} / 1$. The lanthanum is used as a stand-in for rare earths in the Tramex feed solutions.

Figure 5 shows a calibration curve prepared with the diluted standards.

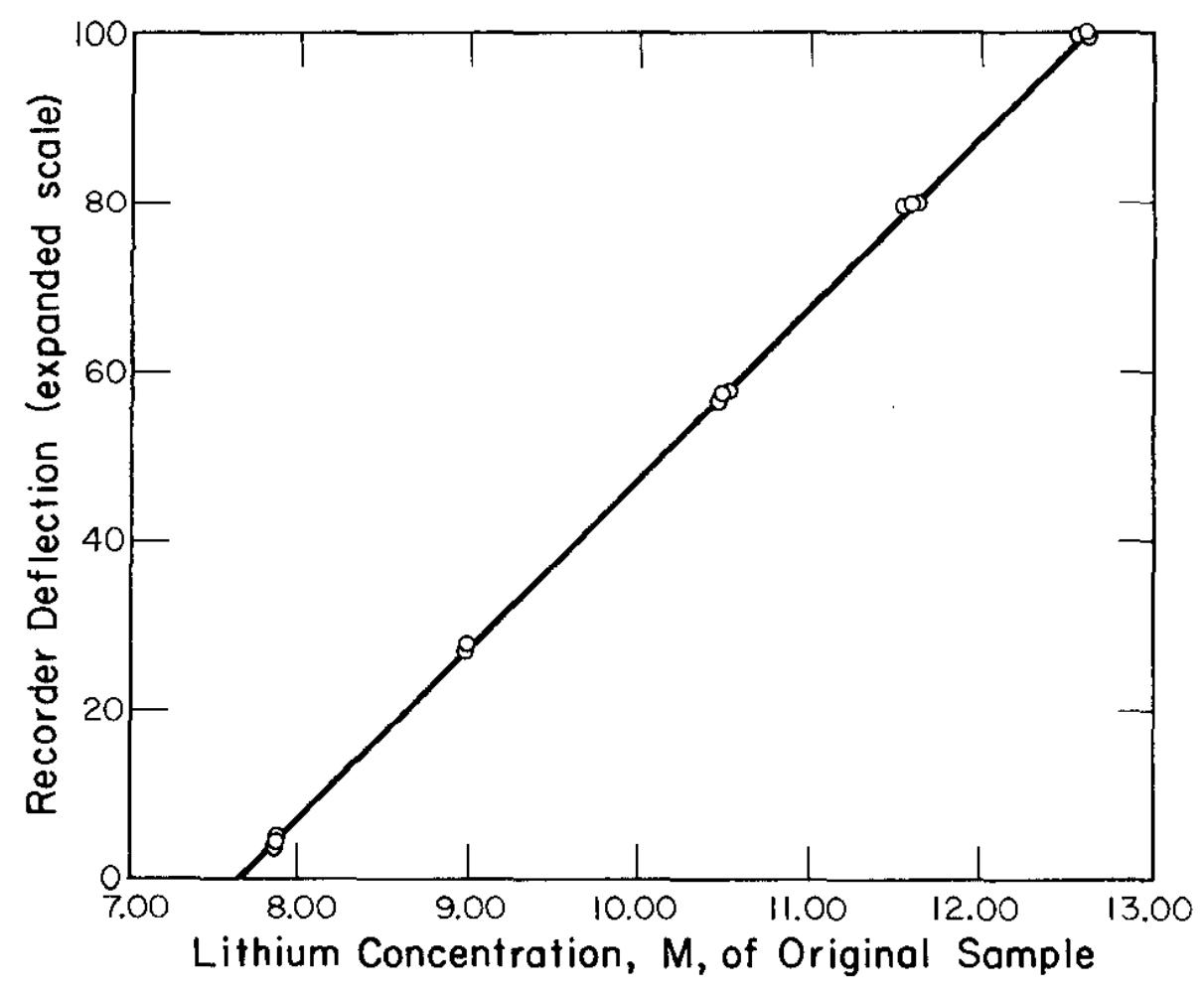

FIG. 5 LITHIUM CALIBRATION CURVE 


\section{PROCEDURE}

Tramex process samples and standards that bracket the estimated value of each sample are run in dupllcate by the following procedure: Samples containing about $18{ }^{244} \mathrm{Cm} / 1$ and $11.0 \mathrm{M}$ LICl are diluted manually 1000-fold with $0.05 \mathrm{M} \mathrm{HNO}_{3}$. The alpha activity of diluted samples is approximately $10^{8} \mathrm{dis} /(\mathrm{min})(\mathrm{ml})$. A $0.500-\mathrm{ml}$ allquot of the dilution Is made slightly alkaline with concentrated ammonlum hydroxide and is carefully transferred to a calclum fluorlde column. After the flow through the column 1 s regulated to about $0.2 \mathrm{ml} / \mathrm{min}$, the sample is washed through the column with $0.1 \mathrm{M}$ ammonium hydroxide-0.005M ammonium nitrate solution. The sample and washes are collected in a 10-ml volumetric flask and are quantitatively diluted with the wash solution. The calcium fluoride column decontaminates the sample by a factor of $5 \times 10^{\circ}$ by removing actinldes and lanthanldes. The decontaminated sample is transferred to three polystyrene cups, which are placed on the automatic sampler. The proportioning pump mixes the internal standard, $10^{-5} \mathrm{M} \mathrm{KC1}$, with each sample and pumps the adjusted sample to the flame photometer at the rate of 40 sample cups per hour. The pumping manifold is shown in Figure 6 .

Since the light emitted by lithium is proportional to the lithium concentration, and the photocelis have a linear response to the emitted light, the recorder stylus deflection is proportional to the lithium concentration in the sample. A recorder chart tracing for a Tramex feed sample and standards is shown in Figure 7 .

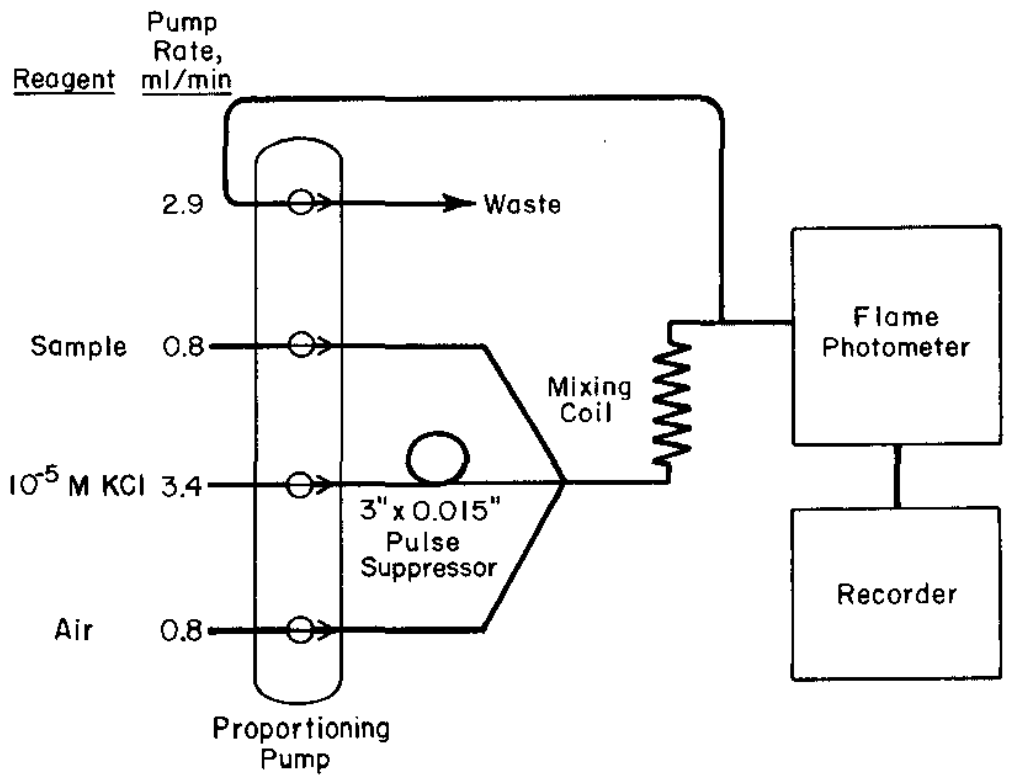

FIG. 6 FLOW DIAGRAM FOR AUTOMATED LITHIUM METHOD 


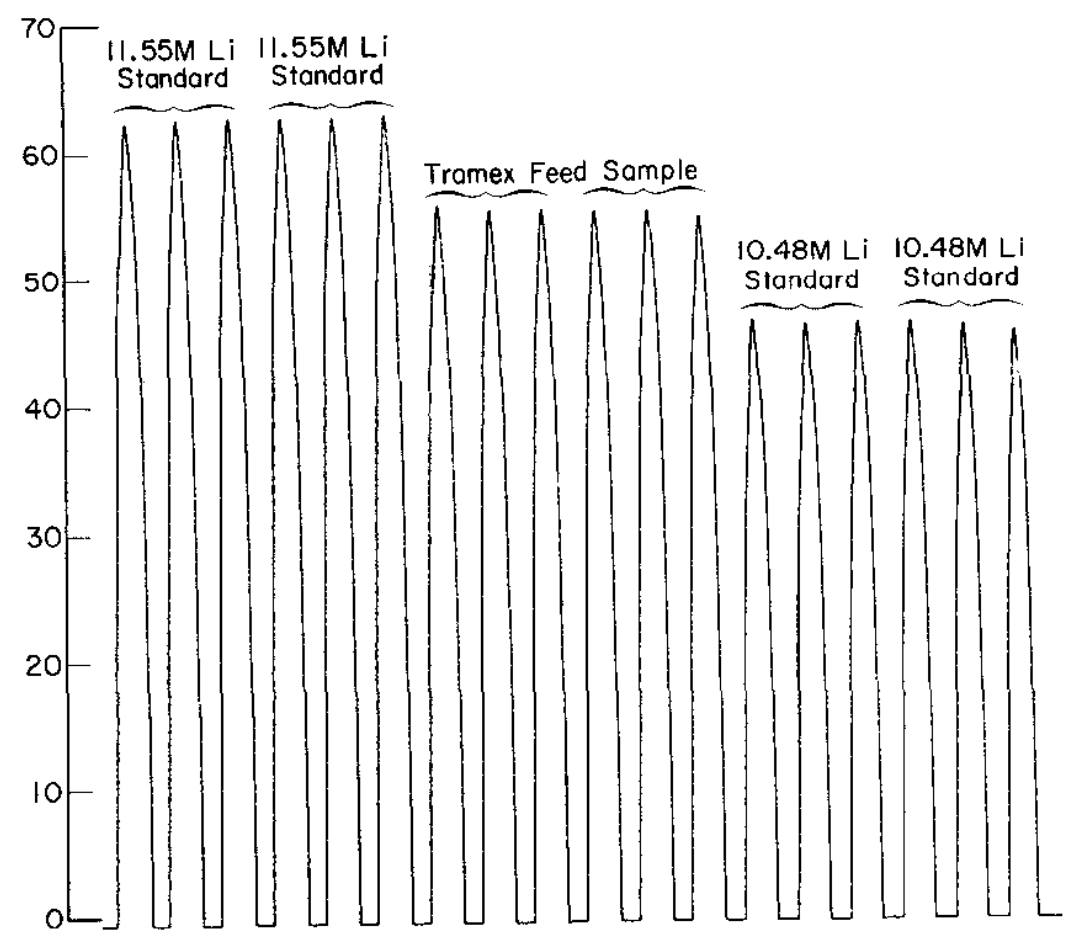

FIG. 7 RECORDER CHART SHOWING RATIOS OF INTENSITIES OF Li $670.8 \mathrm{~m} \mu$ LINES TO K $766.5 \mathrm{~m} \mu$ LINES FOR STANDARDS AND SAMPLE

\section{PRECISION}

The automated flame photometric method has been used successfully during the past eighteen months for obtaining precise lithium analyses on radioactive Tramex feed solutions as well as on nonradioactive samples from varlous scrub and reductant streams. The precision of the analysis was adequate for process control and 1 s summarized in Table $I$.

\section{TABIE I}

Precision of Automated

Flame Photometric Lithium Method

Relative Standard Deviation, of

Instrument noise level

Inactive 11thium solutions

Tramex feed solutions $\pm 0.2$

$\pm 0.4$

$\pm 1.4$ 


\section{BIBLIOGRAPHY}

1. F. P. Treadwell and W. T. Hall. Analytical Chemistry, Vol. II, 9th ed., p. 283-5, John W1ley \& Sons, Inc., New York (1951).

2. M. H. Brown and J. H. Reedy. "Determination of Lithium." Ind. Eng. Chem., Anal. Ed. 2, 304-6 (1930).

3. I. Zlotowsk1 and I. M. Kolthoff. "Polarographic Determination of Potassium, Sodium, and Lithium." Ind. Eng. Chem., Anal. Ed. 14, 473-7 (1942).

4. H. P. Holcomb. "Removal of Radioactive Actinides and Lanthanides from Aqueous Solutions with Calcium Fluoride Prior to Flame Photometric Determination of Lith1um". Anal. Chem. 36, 2360-1 (1964).

5. H. P. Holcomb. "Separation of Americlum from Curium with Calcium Fluoride." Anal. Chem. 36, 2329-32 (1964).

6. R. D. Britt. Automat1c Colorimetric Determination of Uranium and Neptunium. USAEC Report DP-840, E. I. du Pont de Nemours \& Co., Savannah River Laboratory, A1ken, S. C. (1963).

7. Automat1c Chemical Analysis. Ed1ted by Ralph H. Muller and others. Ann. N. Y. Acad. Sc1. 87, Art. 2, 609-951 (1960). 